\title{
CLIMATIC FACTORS AFFECTING THE POPULATION DYNAMICS OF LENTIL APHID IN INNER TERAI REGION OF NEPAL
}

\author{
S. Neupane* and S. Subedi \\ Nepal Agricultural Research Council, National Maize Research Program, Rampur, Chitwan
}

\begin{abstract}
Population dynamics of lentil aphid Aphis craccivora (Hemiptera: Aphididae) was assessed in relation with climatic parameters at the research field of National Maize Research Program (NMRP), Rampur, Chitwan during winter season of two consecutive years 2016 to 2018. The experiment was organized in randomized complete block design consisting 20 lentil varieties with three replications. The crop was sown during last week of November in both the years. The daily meteorological parameters like maximum temperature (Tmax), minimum temperature (Tmin), relative humidity $(\mathrm{RH})$ and rainfall $(\mathrm{Rf})$ were recorded at the meteorological station located in NMRP, Rampur, Chitwan and then converted into weekly basis as the standard meteorological week (SMW) with correspondence to weekly population of aphid. The incidence of aphid was started from $2^{\text {nd }}$ SMW of January $(2$ aphid/plant $/ 10 \mathrm{~cm}$ apical twigs) during both experimentation years. Initially the population was low and gradually increased and reached to its peak (49 aphid/plant/10cm apical twigs) on $9^{\text {th }}$ SMW i.e. first week of March with correspondence to weather parameters viz. maximum and minimum temperature $\left({ }^{\circ} \mathrm{C}\right)$, relative humidity $(\%)$ and rainfall $(\mathrm{mm})$ were $30.80,15.34,67.72$ and 0 , respectively over the years. The aphid population had significant positive correlation with Tmax $(r=0.94)$ while the Tmin showed highly significant correlation $(r=0.99)$. The relative humidity $(\mathrm{RH})$ had non significant negative correlation $(r=-0.90)$ and rainfall $(R f)$ showed non significant negative impact $(r=-0.15)$ with aphid population. The regression model developed could explain $99 \%$ variation in aphid population in different cultivars of lentil.
\end{abstract}

Keywords: Aphis craccivora, Lens culinaris, Temperature, Relative humidity, Rainfall,

\footnotetext{
* Corresponding author: sarusanu2017@gmail.com
} 


\section{INTRODUCTION}

Lentil (Lens culinaris Medik ) is a major grain and widely distributed legume crop grown under a broad range of climates in many developing countries (Turk et al., 2004). This crop is grown mainly as an inexpensive source of high quality protein in human diets (Salehpour et al., 2009). It is one of the most important and highly commercialized pulse crops among the grain legumes in terms of area (206969 ha), production $(254308 \mathrm{mt})$ and productivity $\left(1229 \mathrm{~kg} \mathrm{ha}^{-1}\right)$ which shares almost $62 \%$ of total area and $65 \%$ of total production of pulses and also rates the higher consumer preference in Nepal (MoALD, 2017). However, the lentil average yields in our country yet low as compared to other countries due to many constraints like insect pest and diseases incidence, delay sowing and others management practices. Among different insect pests of lentil, aphid (Aphis craccivora Koch.) infestation is one of the major problems and widely distributed throughout the world.

Aphid causes damage directly by sucking the phloem from the different parts of the plants (Ali and Rizvi, 2007). Aphids feed on plant sap, disrupting the normal plant growth pattern including reduction in root and nodulation growth. At high aphid densities, plants are deformed; stunted and seed set is reduced (Sharma et al., 2014).

The population dynamics of this pest considered to be highly influenced by prevailing weather condition particularly temperature and relative humidity. Several studies have been indicated that weather plays an important role on the aphid appearance, multiplication and disappearance (Srivastava and Srivastava, 1972; Roy, 1975; Kumar et al., 1999; Srivastava, 1999; Vekaria and Patel, 2000). The efforts have been made by Kishor et al. (2019) to correlate the temperature and relative humidity with the incidence and multiplication of aphid in the lentil crop. The changes in aphid population with change in weather parameters enable to forecast the population of lentil aphid under changing scenarios of climate using statistical approaches. Statistical forecasting model is the best approach that would be helpful to provide the information regarding incidence of pest in an advance based on medium range weather forecast. Thus, an attempt has been made to quantify the relationship between weather parameters and appearance, development of aphids in lentil crop at inner Terai region of Nepal.

\section{MATERIALS AND METHODS}

The study was conducted on lentil $(2 n=14)$ crop during winter season of two consecutive years 2016 to 2018 at the research field of National Maize Research Program (NMRP), Rampur, Chitwan. Geographically, the location is situated at $27^{\circ} 40^{\prime} \mathrm{N}$ latitude and $84^{\circ} 19^{\prime} \mathrm{E}$ longitude at an altitude of $228 \mathrm{~m}$ above mean sea level having humid and subtropical climate with cool winter and hot summer. The study was laid down in randomized block design consisting 20 lentil varieties received

from Grain Legumes Research Program (GLRP), Banke as a collaborative trial with three replications. The crop was sown during last week of November in both the 
years. The plots were maintained following the recommended agronomic practices in same manner for all the treatments. All the plots were kept free from any insecticidal spray throughout the crop period. The number of aphids per $10 \mathrm{~cm}$ of the main shoot of the 10 pre-labeled randomly selected plants from each plot was counted at weekly interval from the day of aphid appearance in the field and then was averaged. Twenty varieties were cultivated in each year and each variety was raised in three plots. It means that every year lentil was cultivated in $(20 \times 3) 60$ plots and every sampling day observation was done on $(60 \times 10) 600$ plants. The daily meteorological parameters like maximum temperature (Tmax), minimum temperature (Tmin), relative humidity $(\mathrm{RH})$ and rainfall (Rf) were recorded at the meteorological station located in the National Maize Research Program, Rampur, Chitwan and then converted into weekly basis against the standard meteorological week (SMW) with correspondence to weekly population of aphid. The pooled data of aphid population over the years was taken for the correlation and regression analysis. The weekly population of aphid was considered as dependent variable and correlated with corresponding weekly weather parameters as independent variables. On the bases of significant correlation coefficients between aphid population and weather variables, stepwise regression study was performed to develop statistical forewarning model. Aphid populations are influenced not only by a single weather variable, but by the interaction effect of more than one variable. Hence, multiple regression models were developed based on significant correlation coefficients between aphid population and weather variables by using stepwise regression method for predicting aphid population.

The multiple linear regression model used as follows;

$$
\boldsymbol{y}=\boldsymbol{\beta}_{0}+\boldsymbol{\beta}_{1} \boldsymbol{w}_{1}+\boldsymbol{\beta}_{2} \boldsymbol{w}_{2}+\boldsymbol{\beta}_{3} \boldsymbol{w}_{3}+\boldsymbol{\beta}_{4} \boldsymbol{w}_{4}
$$

Where $y=$ Response or dependant variable i.e. aphid per plant

$$
\begin{aligned}
& \boldsymbol{\beta}_{0}=\text { Constant, } \beta_{(1-4)}=\text { Un-standardized coefficient for each predictor } \\
& \text { variables } \\
& \boldsymbol{w}_{\mathbf{1}}=\text { Average Tmax in }{ }^{0} \mathrm{C}(\text { During SMW) } \\
& \boldsymbol{w}_{2}=\text { Average Tmin in }{ }^{0} \mathrm{C}(\text { During SMW) } \\
& \boldsymbol{w}_{3}=\text { Total Rf in mm (During SMW) } \\
& \boldsymbol{w}_{4}=\text { Average RH (\%) (During SMW) }
\end{aligned}
$$

Here, the aphid per plant is a response variable where as average Tmax, Tmin, RH and total $\mathrm{Rf}$ are the predictor variables. MS-Excel computer package program software version 7 was used for correlation and regression analysis.

\section{RESULTS}

\section{Population dynamics of lentil aphid}

The incidence of aphid was started from second standard meteorological week (SMW) (2 aphid/plant/10 cm apical twigs) during year 2017 and 2018. Initially the 
population was low and gradually increased and reached to its peak (49 aphid/plant/10cm apical twigs) on $9^{\text {th }}$ standard meteorological week. So far as the effect of weather parameters is considered, the maximum aphid population was recorded during $9^{\text {th }}$ SMW when corresponding weather parameters viz. maximum and minimum temperature $\left({ }^{\circ} \mathrm{C}\right)$, relative humidity $(\%)$ and rainfall $(\mathrm{mm})$ were 30.80 , 15.34, 67.72 and 0 , respectively over the years 2017 and 2018 (table 2). The meteorological data during crop period (2016-2018) is shown in table 1.

Table 1. Meteorological data during crop period (2016/17- 2017/18)

\begin{tabular}{lccccc}
\hline Year/Month & Max temp $\left({ }^{\circ} \mathrm{C}\right)$ & Min. temp $\left({ }^{\circ} \mathrm{C}\right)$ & Relative humidity $(\%)$ & Total rainfall $(\mathrm{mm})$ \\
\hline Nov-16 & 28.5 & 13.7 & 92.5 & 0 \\
Dec-16 & 23.8 & 10.1 & 95.8 & 0 \\
Jan-17 & 24 & 8.1 & 84.7 & 13.8 \\
Feb-17 & 26.4 & 12.3 & 79.2 & 3.4 \\
Mar-17 & 29.5 & 16.7 & 68.7 & 64.5 \\
Apr-17 & 33.4 & 21.7 & 72.4 & 77.6 \\
\hline Nov-17 & 29.2 & 15.6 & 91.3 & 0 \\
Dec-17 & 25.5 & 11.6 & 94.8 & 0 \\
Jan-18 & 20.9 & 8.5 & 95.5 & 0.6 \\
Feb-18 & 26.4 & 12.6 & 86.8 & 0 \\
Mar-18 & 32.6 & 18 & 70.6 & 26 \\
Apr-18 & 34.5 & 22.3 & 68.1 & 35.1 \\
\hline
\end{tabular}

Table 2. Population dynamics of aphid on lentil in relation to meteorological parameters during winter season of 2017-2018

\begin{tabular}{l|l|l|l|l|l|l}
\hline $\begin{array}{c}\text { Year: 2017 and } \\
\text { 2018(Month) }\end{array}$ & SMW & $\begin{array}{c}\text { Mean no of } \\
\text { aphid/plant }\end{array}$ & $\begin{array}{c}\text { Tmax } \\
\left({ }^{\circ} \mathrm{C}\right)\end{array}$ & Tmin $\left({ }^{\circ} \mathrm{C}\right)$ & $\begin{array}{c}\mathrm{RH} \\
(\%)\end{array}$ & $\mathrm{Rf}(\mathrm{mm})$ \\
\hline January & 2 & 7 & 22.50 & 6.14 & 90.44 & 0.00 \\
January & 3 & 13 & 23.20 & 7.66 & 90.23 & 0.00 \\
January & 4 & 19 & 23.63 & 9.91 & 87.36 & 14.40 \\
February & 5 & 25 & 24.39 & 10.51 & 86.69 & 0.00 \\
February & 6 & 31 & 24.96 & 12.21 & 84.21 & 0.00 \\
February & 7 & 40 & 26.75 & 12.98 & 81.71 & 0.00 \\
February & 8 & 44 & 27.66 & 14.27 & 79.01 & 3.40 \\
March & 9 & 49 & 30.80 & 15.34 & 67.72 & 0.00 \\
\hline
\end{tabular}

Note: SMW- Standard Meteorological Week, Tmax- maximum temperature, Tmin- minimum temperature, RH- relative humidity, Rf-rainfall, ${ }^{\circ} \mathrm{C}$ - degree centigrade, $\mathrm{mm}$ - millimeter, \%-percentage 


\section{Correlation between lentil aphid and weather parameters}

The combined correlation analysis of aphid population with meteorological factors over the years 2017 and 2018 showed that the aphid population had significant $(\mathrm{P}=0.05)$ positive correlation with maximum temperature Tmax $(\mathrm{r}=0.94)$ while the minimum temperature (Tmin) showed highly significant $(\mathrm{P}=0.004)$ correlation $(\mathrm{r}=0.99)$. The relative humidity $(\mathrm{RH})$ had non significant $(\mathrm{P}=0.07)$ negative correlation $(\mathrm{r}=-0.90)$ and rainfall $(\mathrm{Rf})$ showed non-significant $(\mathrm{P}=0.525)$ negative impact $(\mathrm{r}=-0.15)$ with aphid population (table 3$)$.

Table 3. Correlation coefficient of aphid/plant population on lentil in relation to meteorological factors during winter season of 2017 and 2018

\begin{tabular}{l|l|l|l|l|l}
\hline \multicolumn{1}{c}{ Parameters } & \multicolumn{1}{c}{$\operatorname{Tmax}\left({ }^{\circ} \mathrm{C}\right)$} & $\operatorname{Tmin}\left({ }^{\circ} \mathrm{C}\right)$ & $\mathrm{Rf}(\mathrm{mm})$ & $\begin{array}{c}\mathrm{RH} \\
(\%)\end{array}$ & $\begin{array}{c}\text { Mean } \\
\text { aphid/plant }\end{array}$ \\
\hline $\operatorname{Tmax}\left({ }^{\circ} \mathrm{C}\right)$ & 1.00 & & & \\
$\operatorname{Tm} \min \left({ }^{\circ} \mathrm{C}\right)$ & 0.92 & 1.00 & & & \\
$\mathrm{Rf}(\mathrm{mm})$ & -0.20 & -0.06 & 1.00 & & \\
$\mathrm{RH}(\%)$ & -0.99 & -0.89 & 0.16 & 1.00 & \\
Mean aphid/plant & $0.94 *$ & $0.99 * *$ & -0.15 & -0.90 & 1.00 \\
\hline
\end{tabular}

Note: Tmax- maximum temperature, Tmin- minimum temperature, RH- relative humidity, Rf-rainfall, ${ }^{\circ} \mathrm{C}$ - degree centigrade, mm- millimeter, $\%$ - percentage, *Significant at $5 \%$ level of significance, $* *$ Significant at $1 \%$ level of significance

\section{Forecasting model for lentil aphid}

Aphid / plant $=-237.28+4.80 \times$ Avg. Tmax $\left({ }^{0} \mathrm{C}\right)+3.47 \times$ Avg. Tmin $\left({ }^{0} \mathrm{C}\right)-0.08 \times$ total $\mathrm{Rf}(\mathrm{mm})+1.25 \times$ Avg. $\mathrm{RH}(\%)$

Here, the aphid per plant is a response variable where as average Tmax, Tmin, RH and total $\mathrm{Rf}$ are the predictor variables. The forecasting model relies on average max and min. temperature, total rainfall and average relative humidity to assign aphid per plant and the model has an adjusted $\mathrm{R}^{2}$ value of 0.99 and standard error is 1.29 $(\mathrm{n}=8)$.The $\mathrm{P}$-value for the full model is 0.0004 which is small enough at both $5 \%$ and $1 \%$ level of significance to suggest that at least one of the predictor variables may be useful for the prediction (table 4). The adjusted $R^{2}$ is 0.99 which indicates that the predictor variables explain $99 \%$ of the variance in the response variable (Fig. 1). 


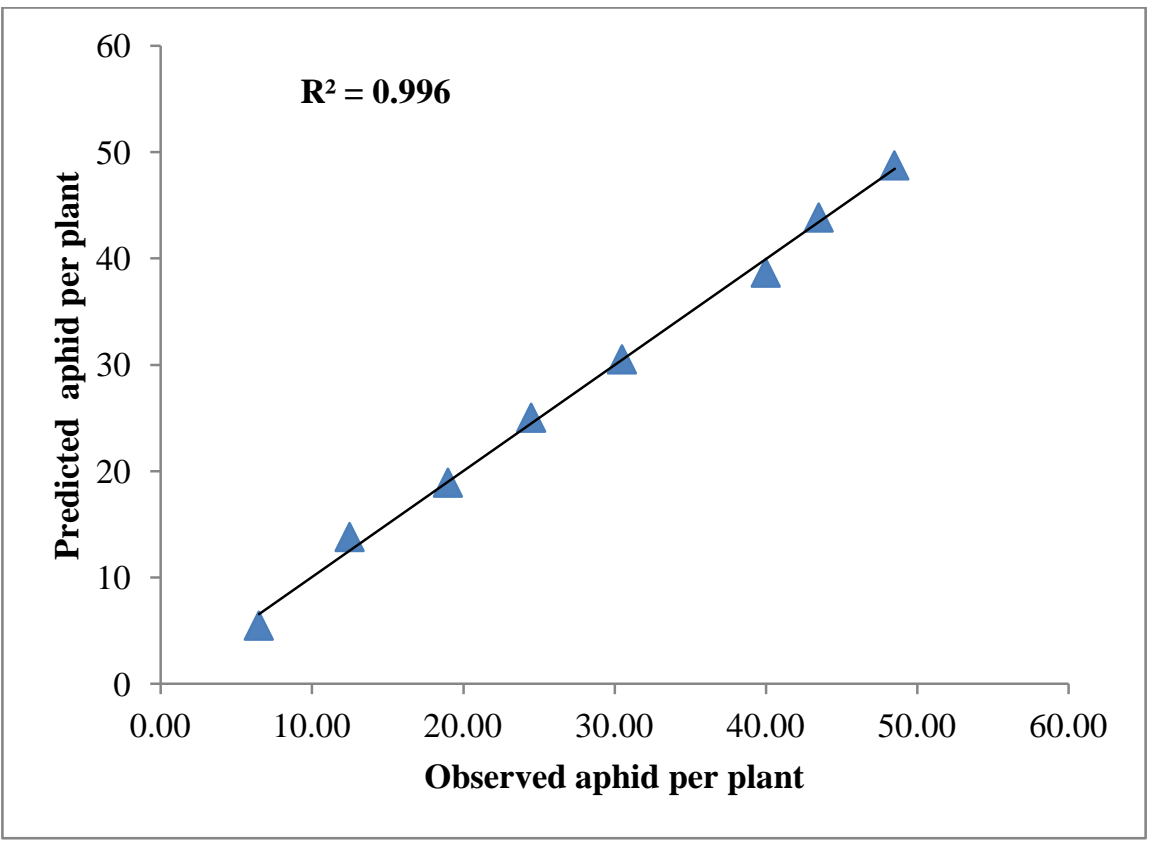

Figure 1. Observed versus predicted aphid per plant as affected by meteorological parameters in Rampur, Chitwan, Nepal 2017/18

These models are simple and easy in calculation and could be used to predict aphid population in lentil crop well in advance (table 5).

Table 4. Parameters of aphid population per plant as affected by average atmospheric temperature $\left(\max\right.$ and $\min { }^{\circ} \mathrm{C}$ ), total rainfall $(\mathrm{mm})$ and average relative humidity $(\%)$

\begin{tabular}{l|l|l|l|l|l|l}
\hline Parameter & Coefficients & SE & t -Stat & P-value & Lower 95\% CI & Upper 95\% CI \\
\hline Intercept & -237.27 & 75.63 & -3.14 & 0.05 & -477.95 & 3.40 \\
Avg. Tmax $\left({ }^{0} \mathrm{C}\right)$ & 4.80 & 1.57 & 3.06 & $0.05^{*}$ & -0.18 & 9.79 \\
Avg. Tmin $\left({ }^{0} \mathrm{C}\right)$ & 3.46 & 0.46 & 7.52 & $0.004^{* *}$ & 2.00 & 4.93 \\
Total Rf $(\mathrm{mm})$ & -0.08 & 0.11 & -0.72 & 0.53 & -0.44 & 0.28 \\
Avg. RH $(\%)$ & 1.25 & 0.471 & 2.65 & 0.07 & -0.24 & 2.75 \\
\hline
\end{tabular}

Note: SE- Standard error, CI- Confidence interval, Avg.-Average, Max-Maximum, Min-Minimum, TTemperature, Rf- rainfall, RH-relative humidity, $\left({ }^{\circ} \mathrm{C}\right)$ - degree centigrade, mm- Millimeter, *Significant, **- Highly significant 
Table 5. Residual output of the forecasting model for lentil aphid

\begin{tabular}{l|l|l|l}
\hline \multicolumn{1}{c|}{ Month/week } & \multicolumn{1}{c|}{$\begin{array}{c}\text { Observed aphid } \\
\text { /plant }\end{array}$} & Predicted aphid/plant & Residuals \\
\hline January second week & 7 & 5.48 & 1.0 \\
January third week & 13 & 13.81 & -1.3 \\
January 4th week & 19 & 18.92 & 0.1 \\
February first week & 25 & 25.03 & -0.5 \\
February Second week & 31 & 30.51 & 0.0 \\
February Third week & 40 & 38.66 & 1.3 \\
February fourth week & 44 & 43.85 & -0.3 \\
March first week & 49 & 48.75 & -0.2 \\
\hline
\end{tabular}

\section{DISCUSSION}

Global warming has great importance regarding to population size, growth, distribution and outbreak of insect pests (Sable and Rana, 2016). The major climatic factors like temperature, light, humidity etc. can be assessed by observation of the rate of change rather than describing direct change in a specific physiological reaction (Overgaard and Sorenson, 2008; Karl et al., 2011). These factors can affect the mortality, fecundity, generation time, multiplication rate, sex ratio and somewhat mutation of any insect species. For instance, with the range of temperature, speed of development can be enhancing but production of deformities and larval mortality will also increased (Chown et al., 2011). Species richness and insect activity varies due to temperature and water availability. In multi climatic factors particularly temperature can extend or reduce the life cycle of insects (Régnière et al., 2012). High thermal thresh hold influence the insects cycle stage, growth or some internal metabolic activities. Tropical species of insects considered to be the high risk of microclimatic variation and behavioral optimization than the temperate regions. Low temperature have a great effect to disturb the physiological, mechanical and behavioral of the various insects (Overgaard and Sorenson, 2008; Karl et al., 2011). It can change the chemical ingredients and causing dehydration of the cells or maintaining body fluids keeping liquids below melting point (Sinclair et al., 2003). Insects could not bear the challenge against high and low thresh hold temperatures. High mortality was observed and somewhat developmental rate was affected and also performed the successful insect modeling that can aid to analyze the insect population response and behavior against climatic change (Karl et al., 2011; Régnière et al., 2012). New research shows that insect species living in warmer areas are more likely to undergo rapid population growth because they have higher metabolic rates and reproduce more frequently. Lower winter mortality of insects due to warmer winter temperatures could be important in increasing insect populations (Harrington et al., 2001). 
The finding of this experiment was supported by Hossain et al. (2006) who reported that lentil aphid appeared in the field during first week of January and the maximum aphid population was recorded in the first week of February, but the population reached to the peak in the last week of January, subsequently rainfall caused a sudden reduction of aphid population in latter dates. Aphid population and infestation increased with the delayed dates of sowing. Hossain et al. (2006) reported that the lentil crop sown in November received less aphid infestation and consequently produced higher yield than the crop sown in December. The present findings supported by the reports of the Dalwadi et al. (2007) who worked out the correlation coefficient between weather parameters and pest population and reported that maximum and minimum temperature had significant positive correlation with aphids population whereas relative humidity and rainfall showed negative association. Prasad et al. (2008) reported that aphid population had significant positive association with maximum temperature, minimum temperature and negative association with relative humidity and rainfall. In the earlier work Hasan et al. (2009) reported that among the different environmental factors maximum temperature and minimum temperature positively correlated with aphid population while rainfall and relative humidity negatively correlated with aphid population.

\section{CONCLUSION}

The result of present findings concluded that weather parameters like temperature, rainfall and humidity were found to significant influence on initiation and development of lentil aphid in inner terai region of Nepal. Predictions from insect forewarning models under changing scenarios of climate, pest population could be managed efficiently through ecological manageable practices like timely application of insecticides, adjustment of sowing time and selection of varieties etc. that would be helpful to obtained higher yield.

\section{ACKNOWLEDGEMENTS}

The authors are grateful to Nepal Agricultural Research Council for funding, National Maize Research Program and Grain Legumes Research Program for providing seed and research facilities, respectively.

\section{REFERENCES}

Ali, A. and Rizvi, P.Q. (2007). Development and predatory performance of Coccinella septempuncutata L. on different aphid species. Journal of Biological Science, 7:14781483.

Chown, S.L., Sorensen, J.G. and Terblanche, J.S. (2011). Water loss in insects: An environmental change perspective. Journal of Insect Physiology, 57: 1070-1084.

Dalwadi. M.M., Korat, D.M. and Tank, B.D. (2007). Population dynamics of major insect pests of indian bean in relation to weather parameters. Research on Crops, 8: 672-677. 
Harrington, R., Fleming, R.A. and Woiwod, I.P. (2001). Climate change impacts on insect management and conservation in temperate regions. Can they be predicted? Agricultural and Forest Meteorology, 3: 233-240.

Hasan, M.R., Ahmad, M., Rahman, M.H. and Haque, M.A. (2009). Aphid incidence and its correlation with different environmental factors. Journal of Bangladesh Agriculture University, 7: 15-18.

Hossain, M., Ferdous, J. and Salim, M. (2006). Relative Abundance and Yield Loss Assessment of Lentil Aphid, (Aphis craccivora Koch) in Relation to Different Sowing Dates. Journal of Agriculture \& Rural Development, 4:101-106.

Karl, I., Stoks, R., De Block, M., Janowitz, S.A. and Fischer, K. (2011). Temperature extremes and butterfly fitness conflicting evidence from life history and immune function. Global Change Biology, 17: 676-687.

Kishor, D.R., Prasad, R., Moses, S. and Singh, P.P. (2019). Population dynamics of aphid and pod borer on lentil and their natural enemies during rabi Season 2017 at Pusa, Samastipur. Current Journal of Applied Science and Technology, 32: 1-6.

Kumar, J., Malik, Y.P. and Singh, S.V. (1999). Forecasting models for outbreak of Lipaphis erysimi on some cultivars of mustard, Brassica juncea. Indian Journal of Entomology, 61: 59-64.

Ministry of Agriculture and Livestock Development. (2017). Statistical information on Nepalese Agriculture 2016/17. Agri-Business Promotion and Statistics Division, Ministry of Agriculture and Livestock Development, Kathmandu, Nepal.

Overgaard, J. and Sorenson, J.G. (2008). Rapid thermal adaptation during field temperature variations in Drosophila melanogaster. Cryobiology, 56: 159-162.

Prasad, T.V., Nandagopal, V. and Gedia, M.V. (2008). Effect of abiotic factors on the population dynamics of Aphis craccivora Koch in groundnut in Saurashtra region of Gujarat. Indian Journal of Entomology, 70: 309-313.

Régnière, J., Powell, J., Bentz, B. and Nealis, V. (2012). Effects of temperature on development, survival and reproduction of insects: Experimental design, data analysis and modelling. Journal of Insect Physiology, 58: 634-647.

Roy, P. (1975). Population dynamics of mustard aphid, Lipaphis erysimi (Kaltenbach) (Aphididae: Hemiptera) in West Bengal. Indian Journal of Entomology, 37: 318-321.

Sable, M.G. and Rana, D.K. 2016. Impact of global warming on insect behavior-A review. Agricultural Reviews, 37: 81-84.

Salehpour, M., Ebadi, A., Izadi, M. and Jamaati-e-somarin, S. (2009). Evaluation of water stress and nitrogen fertilizer effects on relative water content, membrane stability index, chlorophyll and some other traits of lentil (Lens culinaris L.) under hydroponic conditions. Research Journal of Environmental Science, 3:103-109.

Sharma, O. P., Singh, S. K., Vennila, S., Bhagat, S., Saini, M. R., Kumari, A. and Chattopadhyay, C. (2014) Field Guide of Lentil Pest and their Management. Technical Bulletin No. 36. National Centre for Integrated Pest Management (NCIPM), Indian Council of Agricultural Research, LBS Building, IARI Campus, New Delhi - 110012. India. Pp 36. 
Sinclair, B.J., Vernon, P., Jaco Klok, C. and Chown, S.L. (2003). Insects at low temperatures: an ecological perspective. Trends in Ecology \& Evolution, 18: 257-262.

Srivatsava, A. (1999). Effect of date of sowing and varieties on the incidence of mustard aphid, Lipaphis erysimi (Kalt.) on rapeseed mustard. Journal of Oilseeds Research,16: 380-381.

Srivatsava, A.S. and Srivatsava, J. L. (1972). Ecological studies on aphid, painted bug and saw fly attacking mustard and rape in India. F.A.O. Plant Protection Bulletin, 20: 136140.

Turk, M.A., Tawaha, A.R.M. and Lee, K.D. (2004). Seed germination and seedling growth of three lentil cultivars under moisture stress. Asian Journal of Plant Science, 3: 394-397.

Vekaria, M.V. and Patel, G.M. (2000). Screening of promising Brassica and allied genotypes for resistance against mustard aphid, Lipaphis erysimi Kalt. (Homoptera: Aphididae). Applied Biological Reserch, 4: 75-77. 